\title{
5. Media diversity rules: Analysing the talent chosen by student radio journalists covering Islam
}

\section{A ABSIRACI}

The ethnic composition of the Australian population, coupled with the pursuit of a multicultural society at the official level (Ho, 1990) emphasises the nature of the audience for Australia's media - an audience that is ethnically, culturally and religiously diverse. Yet the content and coverage of the mainstream media does not reflect that diversity particularly in relation to Arabs and Muslims. There are few guidelines for journalism professionals and despite attempts to increase the number of journalists from Muslim or Arab backgrounds in mainstream newsrooms there appears to have been no major paradigm shifts in the way newsrooms cover stories related to Islam. Journalism students at a university in Melbourne completed two newsroom production sessions for one of the city's major community radio stations, as part of their assessment in a semester-long subject. The researchers examined the students' choices of interviewee and coded all bulletins produced over a six week broadcast period in 2010. The data will be used to formulate a baseline for the future study of the diversity of talent used by journalism students in the subject, and to see what lessons may be contained for journalism educators, in the breakdown of stories chosen by students and the composition of interviewees contacted by the students.

Keywords: community radio, ethnic diversity, Islam, multiculturalism

\section{NASYA BAHFEN and ALEXANDRA WAKE RMIT University, Melbourne}

'Doing the right story means looking around your community and asking who is missing? Who is it that I really want to see in the story? Who are my students or my reporters, or friends talking about anyway? 
What am I doing to gain the cultural competence about minority groups that will make my reporting inclusive and accurate?'-Arlene Morgan, Columbia School of Journalism, Pacific Journalism Review, 15(1) 2009

$\mathrm{T}$ IHE ETHNIC composition of the Australian population, coupled with the pursuit of a multicultural society at the official level (Ho, 1990) audience that is ethnically, culturally and religiously diverse. Yet the content and coverage of the mainstream media does not reflect that diversity when it comes to Islam and Muslims. There are few guidelines for journalism professionals and despite attempts to increase the number of journalists from Muslim backgrounds into mainstream Australian newsrooms, there appears to have been no major paradigm shifts in the way newsrooms cover stories related to Islam. The issue of media coverage of Islam or Muslims can be set against a broader context of diversity in the media. Journalism educators face challenges when teaching their students how to adequately cover the diversity of their communities, stemming from either resistance at institutional levels or a lack of structured approaches and guidelines (Nicholson, 2003). The conclusion many educators reach is that future journalists emerge from university ill-equipped to deal with reporting stories that reflect such diversity (Lawrence, 2010; Hernandez, 1995).

Journalism students at a university in Melbourne completed two newsroom production sessions for one of the city's major community radio stations, as part of their assessment in a semester-long subject. Each session involved the preparation and presentation of a five-minute news bulletin. The students made specific choices about their bulletins, in the stories they chose to cover on a particular day, the interviewees they contacted to assist them in telling the story, the angle of each story, the way interviews were edited, and the order of the bulletin. The researchers examined the students' coverage of stories related to Islam and Muslims, and coded all stories in the news bulletins produced over a six week broadcast period in 2010. Together the researchers set a coding system that reflected on the nature of the news organisation for which the bulletins were produced, the level of diversity or homogeneity found in the Muslim or Islam-related stories, and the talent used to illustrate those stories. They advised their students that they were using the data to formulate a baseline for study for the talent used by journalism students in the coverage 
of Muslims, and wanted to know lessons that may be contained for journalism educators, in the breakdown of Islam-related stories chosen by students and the composition of interviewees contacted by the students.

\section{Background}

Journalism students at RMIT University in Melbourne are enrolled in one of two courses - the undergraduate Bachelor of Communication (Journalism) or a Graduate Diploma in Journalism. As part of their studies students are required to complete newsroom shifts for community radio station Triple R. Triple R describes itself as 'Melbourne Independent Radio' and is funded primarily by annual subscriptions paid by listeners. The station describes its audience as:

Life style driven they are couples, young singles and midlife households who are optimistic and either seeking to experience all life has to offer: travel, a career, friends and family or are well established in their life and career with a well developed global perspective. (RRR, 2008)

Before beginning their shifts, students are introduced to the station in lectures and encouraged to listen for a number of days to 'get the feel' for the kind of programming the station favours. The students are urged to read the demographical information about the station and to pitch their stories appropriately.

Throughout their studies at RMIT, students are given lectures and tutorials about ways of expanding their contacts to include the widest possible variety of sources. The journalism subjects that form a key component of the students' degree (encompassing print, radio, television and online journalism) are practical in nature and attempt to incorporate assessment that approximates industry experience. In radio, students are assessed on their preparation and production of news bulletins for Triple R. Concepts of hegemonic discourse and narrative diversity are explained through practical, goal-oriented paradigms that reflect the notion of the journalistic profession as a site of conflict: or to put it simply: on one hand students must file quickly as the deadline for the news broadcast looms, and file using authoritative sources; but on the other hand they must find a variety of voices which will keep happy the managers at a fervently independent and self-depicted 'non-hegemonic' community media outlet. This conflict is explained to the students by the teaching staff(the researchers), but no solution is given to this ongoing newsroom dilemma. 
During the study period (April-June 2010) the researchers supervised the newsroom shifts acting as news editors and participant observers. One of the researchers has worked as a journalist for 25 years in Australia and aboard including three years teaching Arab women in the United Arab Emirates. She continues to work outside the university educating multicultural groups (predominantly Muslim) in basic journalism skills. The other researcher is an active member of the Australian Muslim community. Her broadcast work has been predominantly in indigenous and multicultural broadcasting in Australia and abroad, while her academic work has been across four universities, some with a large number of international students. Both researchers maintain industry practice at the international radio division of Australia's main public broadcaster. On some days there was a third person present to edit the students' copy, a radio news reader and subeditor with more than 20 years experience in the commercial and public broadcasting sectors of Australia broadcasting.

Despite the industry and teaching backgrounds of the researchers with their professional focus on diversity, global media and international students and their experiences of and with Arabic and Muslim culture, prior to this research there was no specific class or lecture for the students within their radio classes about the need to include Muslim voices when reporting on Muslim or Islamic affairs, nor was any reference made to resources assisting journalists with covering Islam and Muslims specifically. However all students have had individual lectures in other core journalism subjects, that cover issues of culturally sensitive or appropriate reporting such as Reporting Diversity (based on the work of Philip, 2005) and Reporting Mental Health and Suicide (based on Skehan, Sheridan Burns \& Hazell, 2007; and other work by the Hunter Institute).

\section{Literature review}

Muslims and the media: a vexed relationship?

Australian media operates as a marketplace of ideas in which anything can be published or broadcast for supply to media consumers (Sani, 2005). Media discussion involving Islamic representatives and spokespeople in the mainstream media runs complementary (and often in contradiction to) Muslim-community produced media. A small scale Islamic public sphere exists in Australia. By the 1990s Muslim organisations in Australia had taken some steps to providing their communities with Islamic media. Salaam, the 
magazine of FAMSY, was established in 1995 and continues to be issued by the organisation on a bimonthly basis. Australian Islamic organisations such as the Muslim Women's National Network of Australia also made inroads in public affairs and media management, establishing contacts with media by through furnishing of opinion pieces in metropolitan newspapers, writing letters to the editors of papers, issuing news releases and providing spokespeople to talk to print and broadcast media outlets. Due to reasons such as prohibitive setup costs and inadequate human and other resources, Islamic media engagement is still in its infancy.

Out of all of Australia's faith groups, Muslim communities suffer from a marked media relations problem - so much so that in 2002, an entire episode of the ABC's Media Watch programme was dedicated to the Australian media's more notable Muslim-bashing cases. Among Australian Muslim discourse there are several schools of thought about community responses to the negative portrayal of Muslims in the mainstream media (Bahfen, in Jakubowicz, 2010):

- The first sees the Western media as inherently anti-Islamic and argues against Muslims in Australia or anywhere else engaging with the media.

- There is another view that promotes the encouraging of young Muslims to enter journalism as a career, based on the idea that the most effective change in attitudes comes from people-to-people contact so that if there were more Muslims in newsrooms, there would be less fear and misunderstanding of Islam through personal interaction with its adherents. Both of the researchers of this article support this view and have tried to encourage and support emerging Muslim journalists and writers, through training sessions for young and/or newly arrived Australians of Muslim refugee background, the distribution of publication opportunities and job vacancies, and through involvement in structured programmes such as the Victorian government's community media internships programme.

- The third response argues in favour of fostering relationships between Muslims and the media, many of whom do not set out to portray Islam or Muslims in a bad light, but who know very little about Islam and are subject to the harsh deadlines and audience stereotypes. Illustrating efforts to establish and maintain this type of contact between journalists and Australian Muslim 
communities are publications such as the Islamic Women's Welfare Council of Victoria media guide (Bedar \& ElMatrah, 2005), the Reporting Diversity resources established by universities and media organisations across Australia under the leadership of journalism academics from Murdoch University in Western Australia, or the Living in Harmony grant one of the researchers project-managed for the Muslim Women's National Network of Australia in Sydney (Bahfen, 2003).

\section{Media power and agenda-setting}

There is general consensus among communication academics, and industry professionals, that the media has the power to set the issue agenda, the information flow, and control the parameters of political debate (Burton, 2007; Jones, 1996; McManus, 1994). The idea of cultural hegemony made popular by the Italian theoriest Antonio Gramsci are popular in Australian newsrooms, even if the ' $h$ ' word is rarely uttered by working journalists. The ideas that Gramsci promoted are well understood by most working journalists:

Ruling groups do not maintain their hegemony merely by giving their domination an aura of moral authority through the creation and perpetuation of legitimating symbols; they must also seek to win the consent of subordinate groups to the existing social order (Lears, 1985, p. 569)

The portrayal of religious and ethnic minorities in the media has been of academic interest for many researchers over the past few decades (Avraham, 2003; Domke et al., 1999; Ojo, 2006; Teo, 2000). The coverage of geopolitical events has generated a substantial degree of intolerance of certain religiously or ethnically defined groups, such as Muslim and Arab-Australians (Avraham, 2003; Dunn et. al, 2004; Ojo, 2006; Zilber \& Niven, 2000). The literature on diversity argues that the media tends to either ignore minorities altogether, or sensationalise them in a negative manner with a focus on issues such as crime, violence, riots or social unrest. Many in the media find it easier to use a form of 'shorthand' by encouraging stereotypes about Arabs or Muslims. For example, it is easier to show an image of a leaky boat to summon the idea of illegal immigrants to Australia, when the statistical data shows that the largest number of illegal immigrants comes by airplane (Harvey, 2009). 
Research on diversity and journalism argues that there are strong imperatives for newsrooms to adjust the manner in which narratives are framed (Dreher 2006; Robie, 2009, Wenger \& Nicholson 2004). This article proposes that embracing diversity allows journalism to reflect changing societal demographics (Wenger \& Nicholson, 2004; Hernandez, 1995)_crucial for a country like Australia whose Muslim demographic is growing (Bouma, Haidar, Nyland \& Smith 2003), and avoid a socially exclusionary news paradigm in which the perspectives encountered by the audience are limited to those reinforced as normative by dominant or hegemonic journalistic forms. In the United States where more studies have been conducted into diversity among trainee journalists, the research has argued need for embracing diversity in newsrooms operated by journalism courses at universities (Nicholson, 2003; Rodriguez, 1997) in which the standards and values expected of staff in the media profession are taught, practised, instilled and implied (through the behaviour and advice of teaching staff). Studies on the journalistic selection of interviewees or talent demonstrate reliance by mass media on the use of hegemonic sources who reflect dominant power hierarchies in ethnically diverse, multiracial societies. In these US-based studies, the use of sources who are predominantly male, representative of the élite, and non-minority has been identified as disproportionate (Kurpius, 2002; Hanson, 1991) while the breakdown of sources by gender has been shown that male sources and voices appear more often than females and are believed to reflect more authoritative roles (Armstrong, 2006; Kurpius, 2002). While women represent 52 percent of the world's population, only 24 percent of people who are interviewed are women, an increase from 17 percent in 1995 and 21 percent in 2005 (North, 2009). Female representation in journalistic sources has been found to be slightly higher in the Pacific region (in which Australia is situated) with 26 percent of people interviewed being women with the number of men featured in news stories also disproportionately higher, at 81 percent (North, 2009). The focus of these studies have historically been the coverage of diverse communities in the United States, or by professional newsrooms in Australia, with little research having been conducted on the selection of sources used by Australian students in their coverage specifically of Islam and Muslims, in the course of their training as future journalists.

\section{Research questions}

Given the lecturers' collective experience and backgrounds with Muslim 
issues and communities, the practical nature of the class, and the independent nature of the community broadcaster, the researchers wanted to know what impact, if any, would there be on the students' choice of talent for stories the students prepared and presented, and in particular:

- would students covering specifically Muslim-related stories used talent that accurately portrayed/represented the Muslim community, or would they use male spokespeople from non-Muslim or hegemonic sources?

- would the news bulletins prepared by the students in general reflect the community news organisations' self-stated description of its audience as widely traveled with a global outlook and an interest in the world around them?

\section{Methodology}

The researchers used mixed methods for this case study. Firstly, the researchers were participant observers during the news bulletin production. Both were lecturers who operated as news directors in the Triple R newsrooms on each day of the broadcast. Participant observation has long been favoured by other social scientists as one way of helping achieve understanding. The researchers also believed it was the best way to study what the students were doing, and why they were making the editorial decisions they did.

Participant observation is a way to collect data in naturalistic settings by ethnographers who observe and/or take part in the common and uncommon activities of people being studied. (De Walt \& De Walt, 2002, p. 2)

Secondly, a content analysis was conducted of the sources/talent used by the students in all of their news bulletins broadcast on the Triple R Midday News for Semester 2, 2010, comprising of 243 news stories. In the categorisation of the stories completed by the student journalists, the researchers drew on the framework of critical discourse analysis that sees the construction of news as a socially-situated linguistic activity (Conboy, 2007) that takes place within, and reflects, the contextual values of the media organisation for which it is broadcast or published (Bednarek 2009; Talbot \& Alia 2007). The researchers set out to determine if the students enrolled in radio journalism were producing stories related to Islam or Muslims that accurately portrayed the views of the Muslim or Arab section of society via their selection of non-elite or non-hegemonic sources, or the 'dial-a-quote' voices available 
on mainstream radio. While the research did not set out specifically to study gender imbalances in Muslim-related stories that formed part of the radio news bulletins, the number of male and female interviewees was included in the analysis. The researchers considered a total of 243 general news stories produced by the undergraduate students over the course of their six-week broadcast between April 19, 2010, and May 28, 2010, of which 17 stories were related to the Muslim community either in Australia or overseas.

The researchers, working together, classified the stories by:

- the date published;

- a category for the article (local, business, health, politics etc); and

- the talent interviewed or quoted

The researchers looked further at the talent used or interviewed and where possible determined if they were: male or female; Arab or Muslim; indigenous; other ethnic; independent, hegemonic or academic. The researchers used a further 1 to 10 category for determining the interest of the story to the radio station's audience, using 1 as the least interesting to 10 for the most interesting, with 'interest' being assessed according to the audience description as provided by the broadcaster in its online and other literature. The researchers also initially aimed to categorise each story involving Arab or Muslim groups as being positive or negative for the communities represented. This was judged by the researchers as a result of their own understandings and experiences of Australian, regional and global Muslim cultures.

To place the categorisation of talent into context, spokespeople from major organisations represented the hegemonic bloc, including representatives of widely quoted major organisations, which had the capacity to influence policy and government decision making on issues. The researchers faced a challenge in determining clearly which groups or organisations were classified as part of this hegemonic bloc. On the criteria of being a widely-quoted organisation which could potentially influence government decision-making, it was determined that bodies such as the Ethnic Communities Council of Victoria or the Asylum Seeker Resource Centre were considered part of the hegemonic bloc because they were working within the rules and structures of Australian society and their spokespeople were required to represent the group, even though the researchers accept that these organisations may find that classification uncomfortable. Those people classified in the second group, as independent, were representative of those being affected by the story but 
Table 1: Examples of categorisation of talent

\begin{tabular}{|l|l|l|l|}
\hline \multicolumn{1}{|c|}{ Story } & \multicolumn{1}{c|}{ Hegemonic } & \multicolumn{1}{c|}{ Independent } & \multicolumn{1}{c|}{ Academic } \\
\hline $\begin{array}{l}\text { Visit by hip hop } \\
\text { artist of Muslim back- } \\
\text { ground }\end{array}$ & $\begin{array}{l}\text { Islamic Council of } \\
\text { Victoria spokes- } \\
\text { person }\end{array}$ & $\begin{array}{l}\text { Local Muslim come- } \\
\text { dian and hip hop fan }\end{array}$ & $\begin{array}{l}\text { Person conducting } \\
\text { research into Islamic } \\
\text { music }\end{array}$ \\
\hline $\begin{array}{l}\text { Attacks on interna- } \\
\text { tional students }\end{array}$ & $\begin{array}{l}\text { National Union of } \\
\text { students }\end{array}$ & $\begin{array}{l}\text { Indian international } \\
\text { student }\end{array}$ & $\begin{array}{l}\text { Lecturer teaching } \\
\text { international sudents }\end{array}$ \\
\hline $\begin{array}{l}\text { Protests over the } \\
\text { opening a mosque in } \\
\text { New York }\end{array}$ & $\begin{array}{l}\text { Council of American } \\
\text { Islamic Relations }\end{array}$ & $\begin{array}{l}\text { New York resident } \\
\text { identifying them- } \\
\text { selves as practising } \\
\text { Muslims }\end{array}$ & NYU academic \\
\hline
\end{tabular}

not representing a particular organisation or group and spoke about an issue or policy decision because they were impacted by it. These included individual Muslim students (as opposed to student organisations); non-mainstream Mus$\mathrm{lim}$ artists and musicians; individual refugees not affiliated with major refugee advocacy groups; or a social commentator of Muslim background sourced via a blog site. Academics were classified as a third category because of their perceived independence from hegemonic groups. Academics were seen as being independent voices (although the researchers accept that there are pressures on all academics which means that there work is not always completely independent). The following table gives examples of how the classification of talent was used to decide if an interviewee was coded as hegemonic, independent or academic.

Other challenges in the categorisation of talent included the fact that it was not always possible to determine the source of information for the story (that is, no talent was quoted), and in most of these cases the researchers determined that they were sourced from the Australian Associated Press wire service. The researchers' pre-existing knowledge of the stories and the people quoted was sometimes drawn on to determine if they were from ethnic groups. In several instances, these decisions were not easy or clear-cut. For example, a story quoting the then Dutch national soccer coach was coded as being an "ethnic" story, although it was focused on sport. In most cases talent was coded as being Arab or Muslim if they were publicly accepted/hailed by the media for being Arab or Muslim.

\section{Key findings}

1. In the news bulletins, the Arab and Muslim community in Melbourne and nationally received a significant amount of positive coverage 


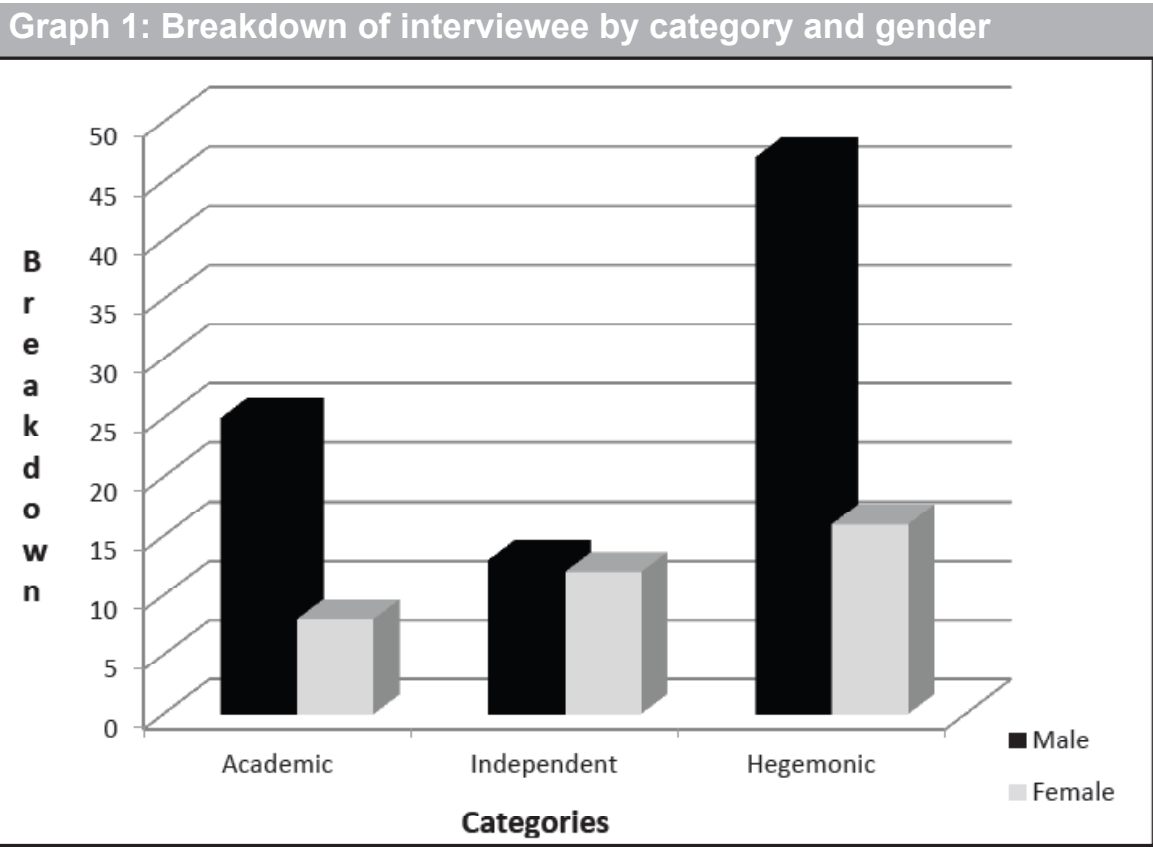

Of the 17 stories dealing with Muslim issues, or quoting people from a Muslim background, 11 were considered to be positive representations of ethnicity, while six were considered neither positive nor negative. During the broadcast period there was a trending issue in the mainstream media about the safety of Indian students in Melbourne, and the comments made by the state's peak Islamic body, the Islamic Council of Victoria, on the issue. The students did contact independent voices in their coverage of this ongoing story, speaking to individual international students. Stories involving the Muslim community-including a former state member of parliament's refusal to sell her home to a Muslim buyer - reflected a wide range of talents from that particular religious community including two Muslim academics and individual female community members, instead of resorting to the peak Muslim body in Victoria which could be determined as a hegemonic organisation, according to the categories used in this research.

2. The student-produced news bulletins were otherwise dominated by male voices representing hegemonic organisations

About half of the 243 stories produced by the students had interviews attached 
to them (120). The breakdown of interviewees/talent is shown in Graph 1. Of these stories with interviews, the overwhelming majority-82-featured male voices, and 38 featured female interviewees/talent. One story (a vox pop) had both male and female voices. The researchers coded the talent as being independent (25), academic (33) and hegemonic (63). Unsurprisingly, most of those coded as being 'hegemonic' voices were male (47) compared with women (16). The 25 'independent' voices had a more egalitarian breakdown of gender with 12 female and 13 male interviewees or talent. However, only 8 of the 'academic' talents were women while 25 were male.

3. The news bulletins reflected the community news organisations'self-stated description of its audience as widely travelled with a global outlook and an interest in the world around them, but there were areas such as human rights and social justice that were not covered as much as politics or international news.

The categories of the most popular stories covered by the bulletins is depicted in Graph 2, and was dominated by state and federal politics (36 stories) along with world/international news (33 stories); and sport (33 stories). Health (30 stories) and crime (29) also figured highly, reflecting a focus on local news. There were 9-16 stories each on the environment, business, technology, education, transport, and entertainment. There was

\section{Graph 2: Breakdown of story categorisation}

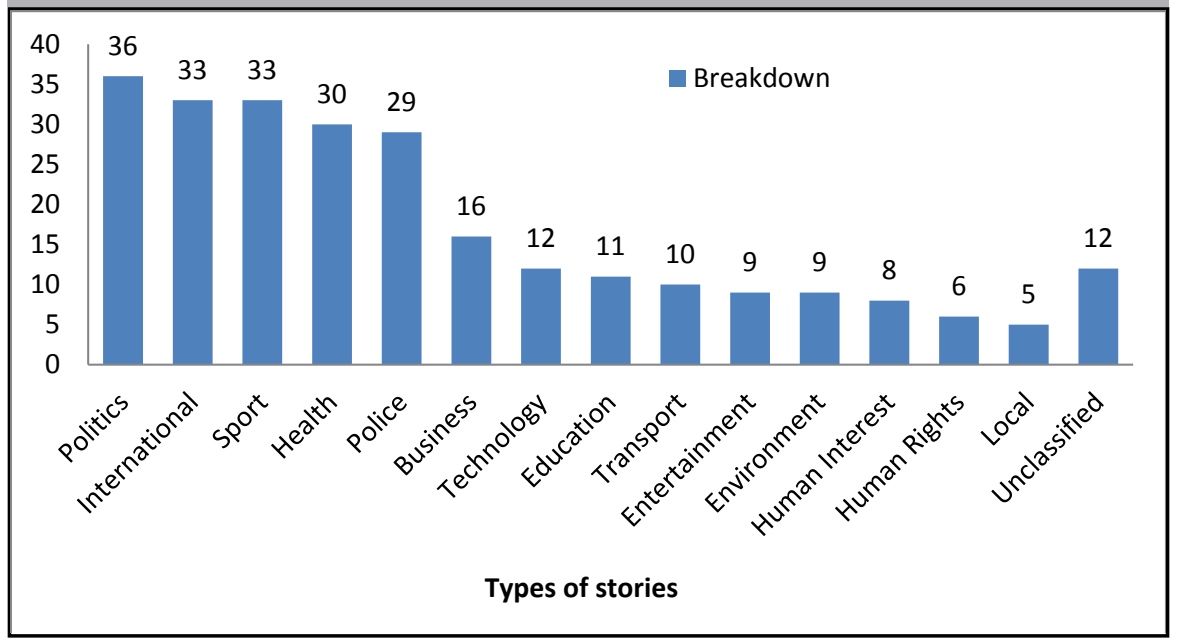


a low incidence of human rights-related news (6) and stories related to multiculturalism, war or social justice (1 each). In relation to the coding of the stories for interest (as perceived according to the community media organisation's description of its listeners), politics (5 stories) topped the list of the 27 stories coded as the most interesting by the researchers for the radio station's audience. Politics was followed by sport (4 stories) and transport ( 2 stories) as the most interesting for the audience. Those stories scoring 9 out of 10 for interest included 2 from independent voices, 2 from academics and 9 from hegemonic sources. The rest were stories the students followed up from wire services.

\section{Discussion}

It had been expected that a newsroom managed by female staff with a particular interest and background or familiarity with Muslim or Arab issues, for an independent community radio station who sees its audience as widely traveled, would see a greater number of independent voices, less reliance on male-dominated hegemonic talent, and a wider representation of groups. Although the focus of this study (the coverage of Muslim or Islamic-related stories) showed a distinct difference in comparison to the angles and choice of interviewees selected by mainstream media, there was a surprisingly low incidence of stories perceived as interesting for this particular news organisation's audience (human rights, multiculturalism in general, and social justice).

This study is restricted in the lessons drawn from the content analysis, in a few areas. Firstly, the study contains implications only with regard to the coverage of Islam and its followers. This particular aspect of the data stood out for analysis because of the personal and practical experiences of Muslim and Arab culture among the teaching staff involved, and because of the Australian mainstream media's focus on Islam and Muslims. Secondly, the lessons drawn from the content analysis would be applicable from an educator's perspective only to trainee journalists in practical courses similar to the course undertaken by the RMIT journalism students. The data used comes from a specific dilemma faced by the postgraduate and undergraduate journalism students at RMIT, in a specific set of circumstances (under which they are expected to emulate a working newsroom and prepare stories for their bulletins in the timeframe required, but at the same time they are expected to fulfill the audience requirements of the major but nevertheless independent 
and community broadcaster to whom they are filing their stories. Finally, the study is also restricted to the analysis of talent or interviewees used by the student journalists in their story preparation for their practical assessment. Radio is one of the most succinct mediums (Phillips \& Lindgren, 2006) and in the hard news context in which the students find themselves for their assessment for this course, it is difficult to delve deeply into the issues covered by their stories with their strict broadcast writing format and tight timeframes for copy and the use of interview excerpts or grabs. While this is the nature of the medium and not a value judgment, it does mean that the analysis of how a particular culture or religious group is covered by this form of journalism can be limited to (for example) which voices are heard or which interviewees are used, instead of areas where future research in the diversity of student journalism could examine, such as the tone or angle of the story.

The researchers intend to use the findings as a baseline for the study of diversity in student production classes at RMIT. The researchers will inform the new cohort of students about the results of the content analysis and compare the results from the next semester's news bulletins. The challenge lies in the accommodation of several - at times conflicting - parameters, including the approximation of a professional newsroom in the preparation and production of the news bulletins, the acknowledgement that as students the "journalists" being overseen by the researchers are experiencing a pressure-filled learning environment and their choice of interviewees may well be determined by accessibility factors instead of ideological ones; the emphasising (outside of the production/practical class) of the community media organisation's discrete values and its highly constructed perception of its audience; and the refraining by journalism educators from the overt influence of the choice of interviewee pursued by students. To assist in the balancing of these needs, the results from this semester's work will be compared to that produced by the students in the next academic year. In the meantime, further research needs to be done on ways to encourage the selection of non-homogenous talent and less "copy-cat" behaviour in relation to mainstream media stories. However, the researchers believe that the simple task of doing this content analysis, and sharing these results with the students, has created an environment in which students better understand the importance of a range of voices in radio news, not just for the sake of equity, but for the provision of a more interesting news bulletin to the listeners of the community radio station. 


\section{References}

Armstrong, C. (2006). Story genre influences whether women are sources. Newspaper Research Journal, 27(3), pp. 66-81.

Anderson, K. and Taylor, A. (2005). Exclusionary politics and the question of national belonging: Australian ethnicities in 'multiscalar' focus. Ethnicities, 5(4), pp. 460-85.

Augoustinos, M., Tuffin, K. and Rapley, M. (1999). Genocide or a failure to gel? Racism, history and nationalism in Australian talk. Discourse \& Society, 10(3), pp. 351-78.

Avraham, E. (2003). Press, politics, and the coverage of minorities in divided societies: the case of Arab citizens in Israel. The Harvard International Journal Of Press/ Politics, 8(4), pp. 7-26.

Bahfen, N. (2003). Building networks between journalism students and Muslims. Retrieved on 27 June 2011, from http://buildingnetworks.nasyabahfen.com/

Bedar, A., and ElMatrah J. (2005). Islam and Muslims in Australia. Islamic Women's Welfare Council of Victoria Media Guide. Retrieved on 27 June 2011, from www. islamicwomenswelfare.org.au/files/MediaGuide.pdf

Bednarek, M. (2009). Evaluation in media discourse: analysis of a newspaper corpus. London: Continuum.

Bouma, G., Haidar, A., Nyland, C. \& Smith, W. (2003). Work, religious diversity and Islam. Asia Pacific Journal of Human Resources, 41(1), pp. 51-61.

Burton, B. (2007). Inside spin: the dark underbelly of the PR industry. NSW: Allen \& Unwin.

Carpentier, N. and Cammaerts, B. (2006). Hegemony, democracy, agonism and journalism. Journalism Studies, 7(6), pp. 964-975.

Coole, C. (2002). A warm welcome? Scottish and UK media reporting of an asylumseeker murder. Media, Culture \& Society, 24(6), pp. 839-52.

Conboy, B. (2007). The language of the news. London: Routledge.

Domke, D., McCoy, K. and Torres, M. (1999). News media, racial perceptions, and political cognition. Communication Research, 26(5), pp. 570-607.

De Walt, KM \& De Walt, BR 2002, Participant observation: a guide for field workers, AltaMira Press, Walnut Creek, CA.

Dreher, T. (2006). Journalists' multicultural responsibilities: business as usual or considering the consequences? Paper delivered at the International Communication Association Annual Meeting.

Dunn, K. M., Forrest, J., Burnley, I. and McDonald, A. (2004). Constructing racism in Australia. Australian Journal of Social Issues, 39(4), pp. 409-30.

Gardiner, G. (2003) Running for country: Australian print media representation of indigenous athletes in the 27th Olympiad. Journal Of Sport \& Social Issues, 27(3), pp. 233-60.

Hall, S. (1998). The work of representation. In S. Hall (Ed.), Representation: cultural representations and signifying practices. London: Sage.

Hansen K. (1991). Source diversity and newspaper enterprise journalism. Journalism Quarterly, 68(3), pp. 474-482. 
Harvey, C 2009, Asylum-seekers arrive by plane, not boat. news.com.au, Retrieved on 9 February 2011, from www.news.com.au/national/asylum-seekers-arrive-byplane-not-boat/story-e6frfkvr-1225790981775

Hernandez, D. (1995). J-school faculties get $\mathrm{F}$ in diversity. Editor \& Publisher, 128(36), pp. 17-18.

Ho, R. (1990). Multiculturalism in Australia: a survey of attitudes. Human Relations, 43(3), pp. 259-272.

Jakubowicz, A. (2010). Diversity and news in Australia. Cosmopolitan Civil Societies Research Centre University of Technology Sydney, \& Institute for Cultural Diversity Presentation to Symposium on News and Inclusion: Journalism and the Politics of Diversity Stanford University, Thursday, 4 March 2010

Jones, N. (1996). Soundbites and spin doctors: how politicians manipulate the media - and vice versa. London: Indigo.

Kurpius, D. (2002). Sources and civic journalism: changing patterns of reporting? Journalism and Mass Communication Quarterly, 79(4), pp. 853-866.

Lawrence, C. (2010). Mission: baby steps to diversity. Quill, 98(1), p. 15.

Lears, TJJ (1985). The concept of cultural hegemony: Problems and possibilities. The American Historical Review, 90(3), pp. 567-93.

McManus, J. (1994). Market-driven journalism: let the citizen beware? London: Thousand Oaks.

Nicholson, J. (2003). Pushing for change. Quill, 91(6), pp. 10-13.

North, L. (2009). The gendered newsroom: how journalists experience the changing world of media. New Jersey: Hampton Press.

Ojo, T. (2006). Ethnic print media in the multicultural nation of Canada: a case study of the black newspaper in Montreal. Journalism, 7(3), pp. 343-61.

Parenti, M. (1986). Inventing reality: the politics of mass media. New York: St. Martin's Press.

Phillips, G. and Lindgren, M. (2006). Australian broadcast journalism. Melbourne: Oxford University Press.

Robie, D. (2009). Diversity reportage in metropolitan Oceania: the mantra and the reality. Media International Australia Incorporating Culture \& Policy, May 2009, 131, pp. 30-45.

Rodriguez, R. (1997). Journalism schools change their standard on diversity. Black Issues in Higher Education, 14(11), pp. 44-46.

Sinclair, J. and Cunningham, S. (2000). Go with the flow: diasporas and the media. Television \& New Media, 1(1), pp. 11-31.

Skehan, J., Sheridan, L. and Hazell, T. (2007). Keeping pace with current issues in reporting suicide and mental illness. Journal of University Teaching and Learning Practice, 4(2), pp. 107-118.

Talbot, M. and Alia, V. (2007). Media discourse: representation and interaction. Edinburgh: Edinburgh University Press.

Teo, P. (2000). Racism in the news: a critical discourse analysis of news reporting in two Australian newspapers. Discourse \& Society, 11(1), pp. 7-49. 
Triple R. (2008). Audience profile. RRR Melbourne independent radio. Retrieved on 19 August 2010, from www.rrr.org.au/sponsorship-and-promotions/audience-profile/ Wagner, V. (2005). Safety goggles required when teaching diversity. Quill, 93(3), pp. 36-37.

Zilber, J. and Niven, D. (2000). Stereotypes in the news: media coverage of AfricanAmericans in Congress. Harvard International Journal of Press/Politics, 5(1), pp. 32-49.

Nasya Bahfen is a lecturer in the School of Media and Communication at RMIT, Melbourne, and she also works as an editor, reporter, producer and presenter with ABC Radio Australia.

Nasya.Bahfen@rmit.edu.au

Alexandra Wake has been a journalist for 25 years and is a lecturer in the School of Media and Communication at RMIT, Melbourne. She has spent time training working journalists at the South African Broadcasting Corporation and three years as a journalism educator at Dubai Women's College in the United Arab Emirates. Wake still works as freelance editor and news reader. Alex.Wake@rmit.edu.au

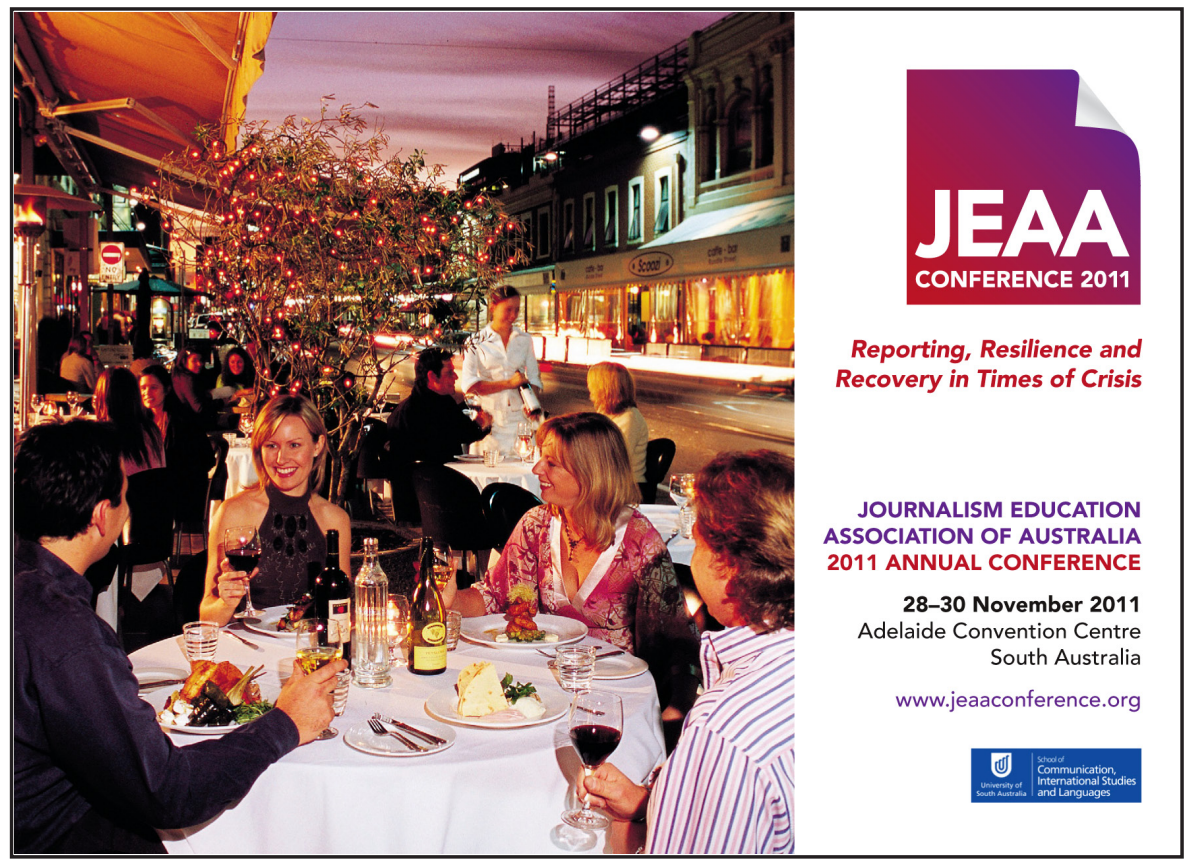

108 PACIFIC JOURNALISM REVIEW 17 (2) 2011 